\title{
Protein XRP2
}

National Cancer Institute

\section{Source}

National Cancer Institute. Protein XRP2. NCI Thesaurus. Code C75567.

Protein XRP2 (350 aa, $\sim 40 \mathrm{kDa}$ ) is encoded by the human RP2 gene. This protein plays a role in both GT Pase activation and protein transport. 